\title{
Economy of Low Density Sowing in Jute (Corchorus olitorius L.)
}

\author{
A. K. Ghorai" and A. K. Chakraborty \\ ICAR-Central Research Institute for Jute and Allied Fibre, Bararckpore, \\ Kolkata 700 121, India \\ *Corresponding author
}

A B S T R A C T

\section{Ke y w o r ds \\ Low density sowing, Population, Fibre yield, Labour savings, Cost reduction}

\section{Article Info}

Accepted: 04 August 2020 Available Online: 10 September 2020
Jute cultivation is a labour-intensive activity. Small and marginal farmers extensively practice high density sowing (HDS) by broadcasting jute seed. High plant stand due to HDS at emergence increases major operational expenses of weeding and thinning, sorting and fibre extraction. To investigate effects of low density sowing (LDS)on production potential of fibre and green biomass and possible reduction in man-days and cost of cultivation, field experiment was conducted at ICAR-CRIJAF farm and it was also repeated through farmers' field trials in four different locations. Results from field experiment confirmed that low density sowing (LDS) of seeds @ 1.9 to $2.6 \mathrm{~kg} \mathrm{ha}^{-1}$ mixed with matching amount (totaling $6 \mathrm{~kg}$ ) of inert jute seed (fried) or river sand @ 4.1 to $3.4 \mathrm{~kg}$ $\mathrm{ha}^{-1}$ is sufficient to obtain 3.0-3.5 $1 \mathrm{ha}^{-1}$ plant population, 36.00-42.55 $\mathrm{q} \mathrm{ha}^{-1}$ fibre yield and 67.5-82.5 $\mathrm{t} \mathrm{ha}^{-1}$ green biomass. LDS significantly reduced labour requirements for major operations by 91-107 man-days ha $^{-1}$ and reduced cost of cultivation by 22916 to 26833 INR $\mathrm{ha}^{-1}$ without compromising fibre yield and total biomass production compared to HDS. In HDS, @ 6.0 kg seed ha ${ }^{-1}$ nearly 30 lakhs jute seedlings emerged and eventually settle down to 4.5-5.0 $1 \mathrm{ha}^{-1}$ plant stand at harvest and yielded $40.45 \mathrm{q} \mathrm{ha}^{-1}$ fibre. About 203 man-days ha $^{-1}$ were required on major operations in HDS. Therefore, sowing jute seeds @ 1.9 to $2.6 \mathrm{~kg} \mathrm{ha}^{-1}$ is recommended for obtaining optimum plant stand, high yield of fibre and green biomass with economy in cost of labour and lesser drudgery.

\section{Introduction}

Jute is the cash crop of the poor and the marginal farmers having scattered land holdings in eastern states of India (West Bengal, Assam, Bihar and Odisha) and Bangladesh (Kumari et al., 2018). More than 95\% farmers of West Bengal are under small and marginal categories with 0.49 ha average land holding (Mandal, 2016). In Bangladesh average land holding is 0.69 ha (George, 2015). Rising cost of cultivation and consequent low income is the major reason of jute area reduction. It is grown mostly as a rainfed, pre-kharif season bast fibre crop and usually farmers broadcast jute seeds in anticipation or with the commencement of occasional nor'wester rains and laddering the field at the earliest opportunity for covering and soil compaction around the seeds for conservation of moisture. Thus, farmers avail the full benefit of nor'wester rains, a scarce resource, in the late afternoons during midMarch-May, pre-kharif season, marked with 
erratic distribution of rainfall and frequent dry spells causing repetition of sowing at times for poor plant stand.

Establishment of required and uniform plant stands is the first important step towards successful crop production to realise the maximum yield potential. Plant density at emergence is governed by the sowing density and the emergence rate. Plant density and evenness in plant distribution at emergence is therefore a key factor explaining production (Liu et al., 2017).

Use of an efficient seeding machine only can achieve evenly distributed plant stand. However, jute farmers continue to practice broadcast widely, mainly due to very low adoption of seed-drill, particularly in clay and clay-loam soil region on improper soil tilth, inclement environmental conditions, small and scattered land holdings and scarcity of resources (water and finance). As there are not any reports (except Ghorai et al., 2013, $2015,2018,2019)$ in the literature of how planting density may alter jute plant stand, fibre yield, green biomass and man-days requirement in broadcast condition, we draw on a limited set of reports from other crops in the literature. Density of planting significantly influenced a number of phenological characters and yield of industrial hemp (Cannabis sativa L.). Low density plantings of industrial hemp grown for bast fibre, resulted in longer and thicker stems at harvest over the high density planting, established economically optimal plant densities and yielded maximum stem dry matter (Hall et al., 2014, Amaducii et al., 2008).

In literature indications are found that jute crop under rainfed condition with $40-50 \%$ deficit rainfall during plant establishment stage (mid-March-May) recorded fibre yield of $29.05 \mathrm{q} \mathrm{ha}^{-1}$ from $2.55 \mathrm{l} \mathrm{ha}^{-1}$ plant population. In conventional high density sowing (HDS), nearly 30 lakhs jute seedlings emerge from the recommended seed rate of $6.00 \mathrm{~kg} \mathrm{ha}^{-1}$ (more than $90 \%$ germination, Ghorai et al., 2019). Out of this colossal plant population, only 4.50-5.00 $1 \mathrm{ha}^{-1}$ remain effective at harvest. This process of jute cultivation requires a total of 234 man-days on major operations involving manual weeding, thinning, sorting (grouping according to plant height) and fibre extraction. An optimum plant population of 3.00-3.50 $\mathrm{ha}^{-1}$ produce $35.00 \mathrm{q} \mathrm{ha}^{-1}$ jute fibre (Ghorai et al., 2019).

To investigate effects of low density sowing on optimal plant stand establishment in broadcast jute, particularly in on-farm conditions, and its impact on production potential of fibre and green biomass and reduction in man-days requirement and cost of cultivation, a field experiment was conducted and validated in 4 different locations (two districts) in 10 farmers' field trials of nearly 1 ha area.

\section{Materials and Methods}

Field experiments were conducted in a randomized block design with seven treatments in three replications at ICARCRIJAF research farm during 2019-20.The experimental soil was sandy clay loam in texture with 44 per cent sand, 28 per cent silt and 28 per cent clay. Its available nitrogen, phosphorus and potassium content was 175 , 32 and $130 \mathrm{~kg} \mathrm{ha}^{-1}$, respectively. Fertilizes dose applied were N: P: K:: 60: 30: 30. Live jute seeds ( $c v$. NJ 7010, germination > 90\%) @ 1.20, 1.50, 1.90, 2.25, 2.60, 4.50 and 6.00 $\mathrm{kg} \mathrm{ha}^{-1}$ is mixed with a matching amount (mixture totaling $6.00 \mathrm{~kg}$ ) of river sand or inert seeds. Seeds were broadcast sown in double crisscross pattern on levelled land. Jute seeds from old stock or inert seeds fried for 5 minutes and mixed thoroughly with live seeds to achieve even distribution of small 
seeds (1000 seeds weight $1.9 \mathrm{~g})$. The field was irrigated after sowing. As a component of integrated method, Pretilachlor 50 EC @ 0.9 $\mathrm{kg} \mathrm{ha}^{-1}$ was applied at 48 hours after sowing with irrigation for composite weed control and thereby to circumvent influence of weeds in the trials. Basal fertiliser dose was N: P: $\mathrm{K}:: 20: 30: 30.1^{\text {st }}$ and $2^{\text {nd }}$ top dressing was made at 21 and 35 DAS with irrigation each time. Other management practices were uniformly followed.

The crop was harvested at 120 DAS. Plant biometry at harvest, fibre yield and manpower employed were recorded. Statistical analysis of biometric and economic data were done following standard procedures.

Pilot scale field trails were also done to validate the concept of low density jute sowing (1.50-2.60 kg ha ${ }^{-1}$ live jute seed + $3.75-4.50 \mathrm{~kg} \mathrm{ha}^{-1}$ inert seeds) in 4 different locations of two districts Murshidabad (one block and clay soil) and North 24 Parganas (3 blocks, alluvial and clay soils) with 10 farmers in one ha area (Photo 1).

\section{Results and Discussion}

\section{Plant stand establishment in altered seed rates}

The emerged plant population and final plant stand establishment under different sowing densities are presented in Table 1. It was observed that emerged plant stand gradually increased with increase in seed rate at sowing, from 34 to 92 plants $\mathrm{m}^{-2}$ for LDS treatments (T1 to T5) while in HDS treatments (T6 and T7) plant densities were extremely high, 280 and 340 plants $\mathrm{m}^{-2}$, respectively. Completion of hand thinning operations led to the ultimate plant stand establishment and these plants remained in the field until harvesting.
Effect of sowing density on plant height, basal diameter, individual plant weight, single plant fibre weight and total green biomass

Plant height attained numerical maximum $(353 \mathrm{~cm})$ for T5 for plant density of 34.4 plants $\mathrm{m}^{-2}$ (Table 2). Otherwise, plant height did not differ much with plant density (Fig.1(a)). Increase in density caused steady decrease in basal diameter from $1.87 \mathrm{~cm}$ in $\mathrm{T} 1$ to 1.57 in $\mathrm{T} 7$ (Fig. 1(b)), single plant weight from 230-255 g plant ${ }^{-1}$ for LDS to 115.7$137.3 \mathrm{~g} \mathrm{plant}^{-1}$ in HDS and fibre weight of single plant from 11.69-12.04 $\mathrm{g}_{\text {plant }}{ }^{-1}$ in LDS to 7.24-8.35 g plant $^{-1}$ in HDS (Fig. 1(c)). Basal diameter, single plant weight and fibre yield attained maximum almost equally for T4 and T5 in LDS.

In LDS, green biomass weight steadily increased from 66.50 to $82.50 \mathrm{t} \mathrm{ha}^{-1}$ with increase in plant density (Fig. 1(d)). T4 yielded highest green biomass (82.50 $\left.\mathrm{t} \mathrm{ha}^{-1}\right)$. Further increase in plant density beyond 35 plants $\mathrm{m}^{-2}$ reduced biomass yield.

\section{Effect of sowing density on fibre yield and green biomass}

Fibre yield steady increased from 32.96 to $42.55 \mathrm{q} \mathrm{ha}^{-1}$ with increase for densities at low density of sowing (Fig. 1(d)), attained maximum for T4 and thereafter yield stabilizes or declines slightly for sowing densities greater than 35 plants $\mathrm{m}^{-2}$. The total green biomass yield increased rapidly as plant density increased (Table 2 and Fig. 1(d)) and attained maximum at 35 plants $\mathrm{m}^{-2}$ at harvest for T4. Thereafter it decreased with further increase in plant density. It suggests that density increases the efficiency of the LDS. However, thereafter yield stabilizes or declines slightly for sowing densities greater than 35 plants $\mathrm{m}^{-2}$. 
Table.1 Labour requirement on major operations and plant stand at different seeding rates

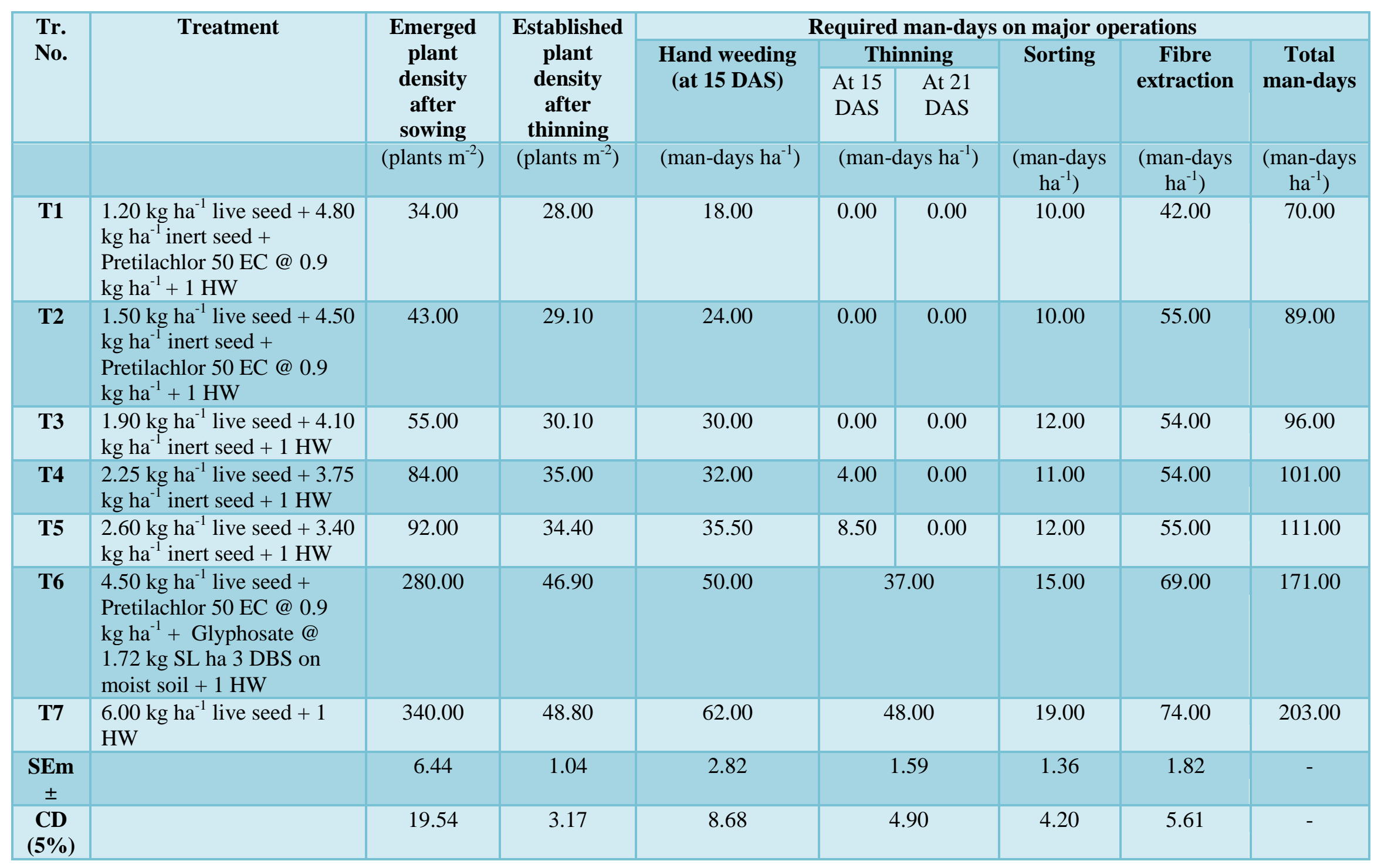


Table.2 Jute plant biometry, fibre yield, harvest index and relative advantages of low density sowing at experimental field

\begin{tabular}{|c|c|c|c|c|c|c|c|c|c|c|c|c|}
\hline \multirow[t]{2}{*}{ Tr. No. } & \multirow[t]{2}{*}{ Treatments } & \multicolumn{8}{|c|}{ Plant Biometry, Jute Fibre Yields and Harvest Indices } & \multicolumn{3}{|c|}{$\begin{array}{l}\text { Man-days, Cost and savings in LSD on } \\
\text { variable operations (weeding and thinning, } \\
\text { harvesting and sorting, and fibre extraction) }\end{array}$} \\
\hline & & $\begin{array}{c}\text { Plant } \\
\text { Populatio } \\
\text { n after } \\
\text { thinning }\end{array}$ & $\begin{array}{c}\text { Plant } \\
\text { density }\end{array}$ & $\begin{array}{c}\text { Plant } \\
\text { height }\end{array}$ & $\begin{array}{c}\text { Basal } \\
\text { Diameter }\end{array}$ & Biomass & $\begin{array}{c}\text { Plant } \\
\text { wt. }\end{array}$ & $\begin{array}{l}\text { Single } \\
\text { Plant } \\
\text { Fibre } \\
\text { wt. }\end{array}$ & $\begin{array}{l}\text { Fibre } \\
\text { Yield }\end{array}$ & $\begin{array}{l}\text { Required } \\
\text { man-days }\end{array}$ & Cost of labour & $\begin{array}{l}\text { Savings on } \\
\text { labour cost } \\
\text { in LDS }\end{array}$ \\
\hline & & $\left(1 \mathrm{ha}^{-1}\right)$ & (plant $\mathrm{m}^{-2}$ ) & $(\mathrm{cm})$ & $(\mathrm{cm})$ & $\left(\mathrm{q} \mathrm{ha} \mathrm{a}^{-1}\right)$ & (g) & $(\mathrm{g})$ & $\left(\mathrm{q} h \mathrm{~h}^{-1}\right)$ & $\left(\right.$ man-days ha $\left.^{-1}\right)$ & $\left(\right.$ INR ha $\left.{ }^{-1}\right)$ & $\left(\mathrm{INR} \mathrm{ha}^{-1}\right)$ \\
\hline T1 & $\begin{array}{l}1.20 \mathrm{~kg} \mathrm{ha}^{-1} \text { live seed }+4.80 \\
\mathrm{~kg} \mathrm{ha}^{-1} \text { inert seed }+ \\
\text { Pretilachlor } 50 \mathrm{EC} @ 0.9 \mathrm{~kg} \\
\mathrm{ha}^{-1}+1 \mathrm{HW}\end{array}$ & 2.80 & 28.0 & 300 & 1.87 & 66.50 & 239.7 & 11.85 & 32.96 & 70.00 & 17500 & 33333 \\
\hline $\mathbf{T 2}$ & $\begin{array}{l}1.50 \mathrm{~kg} \mathrm{ha}^{-1} \text { live seed }+4.50 \\
\mathrm{~kg} \mathrm{ha}^{-1} \text { inert seed }+ \\
\text { Pretilachlor } 50 \mathrm{EC} @ 0.9 \mathrm{~kg} \\
\mathrm{ha}^{-1}+1 \mathrm{HW}\end{array}$ & 2.91 & 29.1 & 339 & 1.93 & 73.40 & 255.3 & 11.69 & 34.10 & 89.00 & 22250 & 28583 \\
\hline T3 & $\begin{array}{l}1.90 \mathrm{~kg} \mathrm{ha}^{-1} \text { live seed }+4.10 \\
\mathrm{~kg} \mathrm{ha}^{-1} \text { inert seed }+1 \mathrm{HW}\end{array}$ & 3.01 & 30.1 & 346 & 1.73 & 67.50 & 230.0 & 11.94 & 36.22 & 96.00 & 24000 & 26833 \\
\hline T4 & $\begin{array}{l}2.25 \mathrm{~kg} \mathrm{ha}^{-1} \text { live seed }+3.75 \\
\mathrm{~kg} \mathrm{ha}^{-1} \text { inert seed }+1 \mathrm{HW}\end{array}$ & 3.50 & 35.0 & 313 & 1.77 & 82.50 & 246.3 & 12.04 & 42.55 & 102.33 & 25582 & 25250 \\
\hline T5 & $\begin{array}{l}2.60 \mathrm{~kg} \mathrm{ha}^{-1} \text { live seed }+3.40 \\
\mathrm{~kg} \mathrm{ha}^{-1} \text { inert seed }+1 \mathrm{HW}\end{array}$ & 3.44 & 34.4 & 353 & 1.71 & 78.12 & 229.7 & 12.02 & 41.41 & 111.67 & 27917 & 22916 \\
\hline T6 & $\begin{array}{l}4.50 \mathrm{~kg} \mathrm{ha}^{-1} \text { live seed }+1.50 \\
\mathrm{~kg} \mathrm{ha}-1 \text { inert seed }+ \\
\text { Pretilachlor } 50 \mathrm{EC} @ 0.9 \mathrm{~kg} \\
\mathrm{ha}^{-1}+\text { Glyphosate @ } 1.72 \\
\mathrm{~kg} \mathrm{SL} \mathrm{ha} 3 \text { DBS on moist } \\
\text { soil + 1 HW }\end{array}$ & 4.69 & 46.9 & 332 & 1.79 & 54.20 & 115.7 & 7.24 & 33.61 & 171.33 & 42833 & 8000 \\
\hline T7 & $\begin{array}{l}6.00 \mathrm{~kg} \mathrm{ha}^{-1} \text { live seed }+1 \\
\text { HW }\end{array}$ & 4.88 & 48.8 & 324 & 1.57 & 66.75 & 137.3 & 8.35 & 40.45 & 203.33 & 50833 & 0 \\
\hline SEm \pm & & 0.13 & 1.3 & 13.99 & 0.03 & 2.14 & 5.08 & 0.29 & 1.34 & 1.66 & 737 & 770 \\
\hline $\begin{array}{c}\text { CD } \\
(5 \%)\end{array}$ & & 0.4 & 4.0 & 42.43 & 0.1 & 4.66 & 15.4 & 0.87 & 4.01 & 5.02 & 2236 & 2373 \\
\hline
\end{tabular}


Table.3 Correlation between different density of sowing and biometry, biomass and fibre yield

\begin{tabular}{|c|c|c|}
\hline Correlation (r) & $\begin{array}{c}\text { LDS } \\
\text { (Live seed 1.2 to 2.6 } \\
\text { kg/ha) }\end{array}$ & $\begin{array}{c}\text { Combined (LDS+HDS) } \\
\text { (Live seed 1.2 to 6 kg/ha) }\end{array}$ \\
\hline Density \& Height & 0.237 & 0.009 \\
\hline $\begin{array}{c}\text { Density \& Basal } \\
\text { Diameter }\end{array}$ & -0.685 & -0.660 \\
\hline Density \& Fibre Yield & 0.998 & 0.250 \\
\hline Density \& Biomass & 0.897 & -0.467 \\
\hline Density \& Single Plant & -0.210 & -0.935 \\
\hline Wt & 0.807 & -0.912 \\
\hline Density \& Single Plant & & \\
\hline Fibre Wt & & \\
\hline
\end{tabular}

Fig.1 Influence of jute plant density on (a) plant height, (b) stem basal diameter, (c) per plant fibre weight, (d) per ha yield of fibre and biomass, (e) per hectare total labour requirement for major operations (weeding, thinning, sorting and fibre extraction), and (f) per hectare net cost savings on major operations
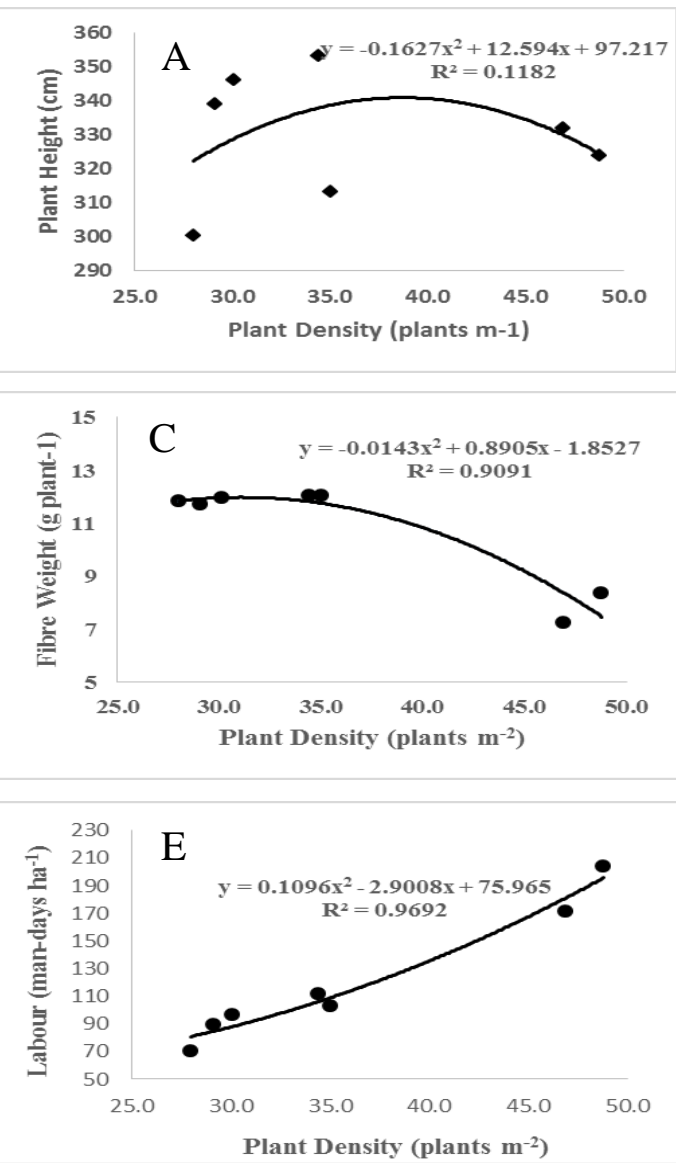
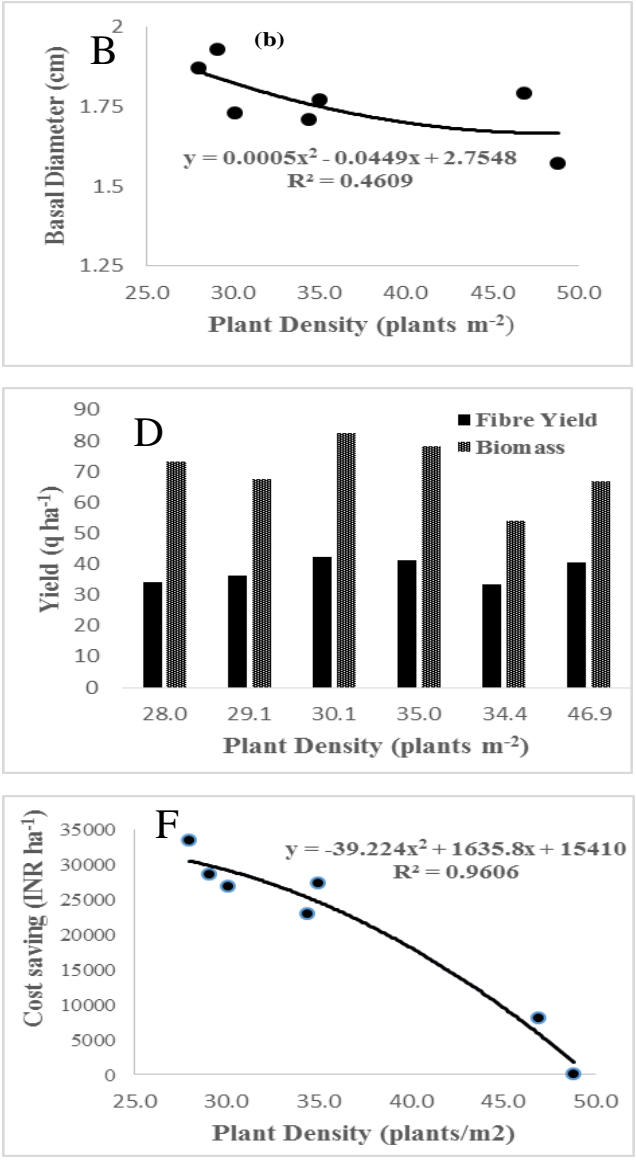
Photo.1 Plant stand with high and low density sowing at farmers' field at Bagdah, District: North 24 PGS, West Bengal

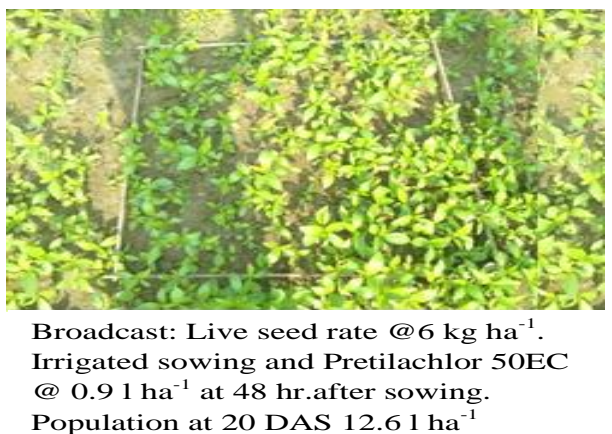

Effect of sowing density on requirement of labour and cost savings for major operations

Treatments T1, T2 and T3 needed only one hand weeding at 15 DAS utilizing 18, 24 and 30 man-days, respectively and required no thinning (Table 1). Treatments T4 and T5 required one hand weeding and a light thinning at 15 DAS requiring $32+4=36$ and $35.5+8.5=44$ man-days, respectively. For two HDS treatments in T6 and T7, one intensive $\mathrm{HW}$ at 15 DAS and two intensive thinnings at 15 DAS and 21 DAS were required and accounted for $50+37=87$ and $62+48=110$ man-days, respectively. Fibre extraction, the most strenuous operation, consumes 74 man days $\mathrm{ha}^{-1}$ in HDS. LDS resulted 20 man-days reduction on this operation and provided relief to farmers, reducing drudgery to a great extent. Total man-days requirement on major operations were 70-111 in LDS (Table 1), while it was 171-203 man-days in HDS. Thus, 60-133 man-days reduction is possible in LDS (Fig 1(f)). LDS with seed rate of 1.20$1.90 \mathrm{~kg} \mathrm{ha}^{-1}$ is an option to reduce dependency on costly human labour and sowing machine to achieve fibre yield of 33$36 \mathrm{q} \mathrm{ha}^{-1}$.

Field trials conducted on 10 farmers field in 1 ha total area during 2019-20 with LDS (1.50-

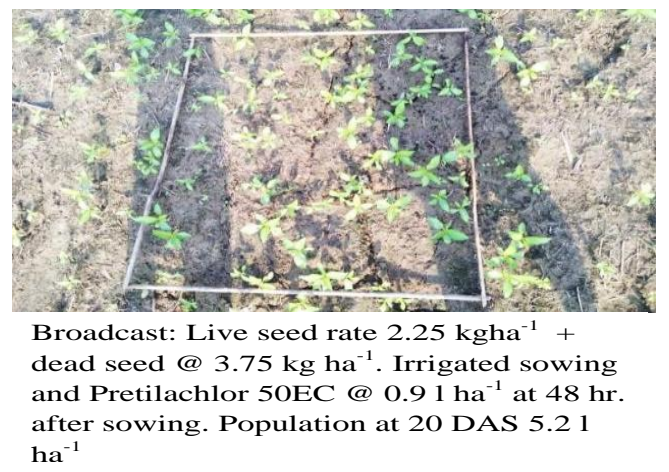

$2.60 \mathrm{~kg} \mathrm{ha}^{-1}$ live jute seed $+3.75-4.50 \mathrm{~kg} \mathrm{ha}^{-1}$ inert seeds) recorded fibre yield in the range of 38-45 q ha ${ }^{-1}$ and it reduced 75-98 man-days $\mathrm{ha}^{-1}$, resulting in labour cost saving in the range of 18750 to $24500 \mathrm{INR} \mathrm{ha}^{-1}$. A view on plant population variation at farmers' field at 20 DAE is in Fig. 2.

In summary, low density sowing (T3, T4 and T5) with a seed rate between 1.90 to $2.60 \mathrm{~kg}$ $\mathrm{ha}^{-1}$ is the optimum seed rate in broadcast which settled down optimum plant density to 30-35 plants $\mathrm{m}^{-2}$, as it contributes in higher fibre yield (36.22-42.55 q ha $\left.{ }^{-1}\right)$, higher biomass (67.50-82.50 $\mathrm{t} \mathrm{ha}^{-1}$ ) and better plant vigour having thicker basal diameter (1.71$1.77 \mathrm{~cm})$, higher plant weight $(230-255 \mathrm{~g}$ plant $\left.^{-1}\right)$, higher fibre per plant $(11.69-12.04 \mathrm{~g}$ plant $^{-1}$ ) over HDS having $40.45 \mathrm{q} \mathrm{ha}^{-1}$ fibre, $66.75 \mathrm{t} \mathrm{ha}^{-1}$ green biomass and low plant vigor of $1.57 \mathrm{~cm}$ basal diameter, $137.3 \mathrm{~g} \mathrm{plant}^{-1}$ plant weight and $8.35 \mathrm{~g} \mathrm{plant}^{-1}$ fibre per plant. In the process, it resulted in significant reduction of labour requirement (by 91-107 man-days $\mathrm{ha}^{-1}$ ) in major operations and cost of fibre production by 22916 to 26833 INR $\mathrm{ha}^{-1}$ to enhance higher economic income. The wage of labour was 250 INRday $^{-1}$

Correlation values between plant density and plant biometry attributes are in Table 3 . Overall correlation between plant density and 
plant height is 0.009 , while for LDS the correlation is very weak $(r=0.237)$, signified density did not affect plant height (Fig 1(a)).

Plant density and basal diameter are inversely correlated $(\mathrm{r}=-0.6605)$ as low density produced thicker stems (Fig 1(b)). Increase in plant density decreased single plant weight and they were strongly inversely related $(\mathrm{r}=$ 0.935) as low density resulted in heavier plants. Similarly, plant density and fibre weight of single plant were strongly inversely related $(\mathrm{r}=-0.912)$ as low density resulted in high amount of fibre per plant (Fig 1(c)). At low density levels, increased biomass per unit area (Fig. 2 (d)) with increased densities suggest that it increases the efficiency and that a population threshold was exceeded between 35 plants $\mathrm{m}^{-2}$ and 46.9 plants $\mathrm{m}^{-2}$.

Increase in stem thickness, plant weight, fibre weight per plant at low density has been reported in industrial hemp and indicated that a population threshold was exceeded, whereby robust, thick individual plants that were common at the lower population and low competition densities diminished with increasing population (Hall et al., 2014).

Thus, a plant density of $30-35$ plants $\mathrm{m}^{-2}$ from a sown seed rate between $1.9-2.6 \mathrm{~kg} \mathrm{ha}^{-1}$ (mixed with matching amount (totaling $6 \mathrm{~kg}$ ) of inert jute seed (fried) or river sand @ 4.1 to $3.4 \mathrm{~kg} \mathrm{ha}^{-1}$ ) is optimum in broadcast jute. It contributes in higher fibre yield (36.22-42.55 $\mathrm{q} \mathrm{ha}^{-1}$ ), higher biomass (67.50-82.50 $\mathrm{t} \mathrm{ha}^{-1}$ ) (Fig 1(d)) and better plant vigour having thicker basal diameter $(1.71-1.77 \mathrm{~cm})$, higher plant weight (230-246 $\left.\mathrm{g} \mathrm{plant}^{-1}\right)$ and higher fibre per plant (11.94 - $\left.12.04 \mathrm{~g} \mathrm{plant}^{-1}\right)$. In the process, it resulted in significant reduction of labour requirement (91-107 man-days ha ${ }^{-1}$ ) in major operations (Fig. 1(e)) and cost of fibre production by Rs.22916 to Rs. $26833 \mathrm{ha}^{-1}$ (Fig 1(f)) to enhance higher income. Plant density more than 35 plants $\mathrm{m}^{-2}$ is not only unproductive and unprofitable in terms of jute fibre or biomass yield but also paves the way to wasteful expenses on extra man-days.

These findings are similar to earlier studies held under rainfed condition with 40-50\% deficit rainfall during plant establishment stage (mid-March-May) in the years 2007-08, 2008-09 and 2009-10 on LDS (Ghorai et al., 2013), wherein it reported an average plant population of $2.551 \mathrm{ha}^{-1}$, mean fibre yield of $29.05 \mathrm{q} \mathrm{ha}^{-1}$, biomass of $50.38 \mathrm{t} \mathrm{ha}^{-1}$, mean plant weight of $197 \mathrm{~g}$ and mean fibre yield per plant of $11.39 \mathrm{~g}$. Whereas, in HDS with an average plant population of $5.241 \mathrm{ha}^{-1}$, recorded $36.90 \mathrm{q} \mathrm{ha}^{-1}$ mean fibre yield, $59.79 \mathrm{t}$ $\mathrm{ha}^{-1}$ biomass, $114 \mathrm{~g}$ plant $^{-1}$ mean plant weight and $7.04 \mathrm{~g}$ plant $^{-1}$ mean fibre yield per plant. Similar manpower reduction under reduced plant density had been reported by Ghorai et al., 2018.

Farmers' field trials on LDS were held during the year 2014 at Murshidabad and North 24 Parganas districts of West Bengal with 8 farmers covering 0.7 ha area. It recorded average plant population of $2.43 \mathrm{l} \mathrm{ha}^{-1}$ and average fibre yield of $30 \mathrm{q} \mathrm{ha}^{-1}$. Whereas, in HDS with plant population of $6.26 \mathrm{l} \mathrm{ha}^{-1}$ yielded $36.29 \mathrm{q} \mathrm{ha}^{-1}$ fibre (Ghorai et al., 2015).

In conclusion, the production strategy for higher fibre yield and biomass production with minimum cost is a necessity in jute cultivation. Low density sowing of jute between 1.9-2.6 kg live seeds $\mathrm{ha}^{-1}$ (mixed with matching amount (totaling $6 \mathrm{~kg}$ ) of inert jute seed (fried) or river sand @ 4.1 to $3.4 \mathrm{~kg}$ ha-1) is an effective way to reduce manpower requirement involving labour-intensive major operations of weeding, thinning, sorting of plants at harvesting and fibre extraction. The economically optimal plant densities of jute grown for bast fibre are $30-35$ plants $\mathrm{m}^{-2}$ yielding 36.00-42.55 $\mathrm{q} \mathrm{ha}^{-1}$ fibre and 67.5- 
$82.5 \mathrm{t} \mathrm{ha}^{-1}$ green biomass. Fibre content was greater at 35 plants $\mathrm{m}^{-2}$ than at higher densities. Economic benefit is achieved in this way through substantial reduction in mandays without compromising fibre yield. It also paved way for higher biomass production in comparison to conventional high density sowing.

\section{References}

Amaducci, S., Zatta, A., Pelatti, F. and Venturi, G. (2008). Influence of agronomic factors on yield and quality of hemp (Cannabis sativa L.) fibre and implication for an innovative production system. Field Crops Res. 107:161-169.

George, R. (2015). The economic lives of smallholder farmers: An analysis based on household data from nine countries. FAO, Rome. http://www.fao.org/3/a-i5251e.pdf

Ghorai, A.K., Saha, S., Saren, B.K., Hembram, P.K., Mandal, B.K., Thokle, J.G., More, S.R., Srilata, T., Jagannadham, G., Tripathi, M.K., Kumar S., Kundu, D.K. and Mahapatra, B.S. (2013). Drought management of jute and mesta crop under deficit rainfall. Technical bulletin No.5/2013, 67 P.

Ghorai, A.K. (2015). Weed control by smothering. TMJ 4.0. Development of lowcost ecofriendly technologies for weed management in jute and mesta. Ann. Rep. ICAR-CRJAF, Technology Mission on Jute, 2014-15, Pp 15.

Ghorai, A.K., Kumar, M. and Roy, S. (2018).
Low cost and ecofriendly weed management technologies for jute. In: Proceed. ISWS Golden Jubilee International Conference on "Weeds and Society: Challenges and opportunities". Held at ICAR-Directorate of Weed Resarch, Jabalpur, India 21-24 Nov 2018, Pp. 243.

Ghorai, A.K. and Chakraborty, A.K. (2019). Low density jute sowing to minimise cost of different operations in integrated weed management system. In: Proceed. International Seminar on Agriskills for convergence in research, industry and livelihood (AGRIL), BCKV, Kalyani, West Bengal, India, from 28 Nov to $01^{\text {st }} \mathrm{Dec}$, 2019, Pp 110.

Hall, J., Bhattarai, S.P. and Midmore, D.J. (2014). Effect of industrial hemp (Cannabis sativa L) planting density on weed suppression, crop growth, physiological responses, and fibre yield in the subtropics. Renew Bioresour. 2014; 2:1.

Kumari, K., Devegowda, S.R. and Kushwaha, S. (2018). Trend analysis of area production and productivity of jute in India. Pharma Innovation J 7(12): 58-62.

Liu, S., Baret, F., Allard, D., Jin, X., Andrieu, B., Burger, P., Hemmerlé, M. and Comar, A. (2017). A method to estimate plant density and plant spacing heterogeneity: application to wheat crops. Plant Methods 13, 38.

Mandal, A. (2016). Comparative study of marginal farms in India vis-a-vis West Bengal; Evidences from Last Decade. Economic Affairs 61(4): 589-598.

\section{How to cite this article:}

Ghorai, A. K. and Chakraborty, A. K. 2020. Economy of Low Density Sowing in Jute (Corchorus olitorius L.) Int.J.Curr.Microbiol.App.Sci. 9(09): 292-300. doi: https://doi.org/10.20546/ijcmas.2020.909.037 